\title{
Reform Reversals and Output Growth in Transition Economies*
}

\author{
Bruno Merlevede \\ University of Antwerp, Prinsstraat 13, B-2000 Antwerp, Belgium \\ and \\ Ghent University, Hoveniersberg 24, B-9000 Ghent, Belgium \\ Bruno.Merlevede@UGent.be
}

June 16, 2003

\begin{abstract}
This paper tests whether there is a macroeconomic cost of a reform reversal during transition. A reform reversal is defined as a downgrading in the level of an average reform indicator. This is important both from an empirical and a theoretical point of view. In the standard empirical framework the current level of reform affects growth negatively, while the lagged level affects growth positively. This nonlinear effect is shown to imply a counterintuitive, short-lived, or at best an insignificant, positive effect of a reversal. From a theoretical point of view however, most models assume a reversal to be costly. The existence of reversal costs is even crucial for gradualist strategies to dominate big bang strategies in the presence of aggregate uncertainty. In a simultaneous equation system with growth and the level of reform as dependent variables we explicitly introduce a reversal parameter. Empirical results suggest that a reversal generates an immediate negative contribution to real output growth. Taking into account the level of reform a country achieved, a reversal is found to be more costly at higher levels of the reform indicator.
\end{abstract}

JEL Classification: O57, P21, P26, and P27

Keywords: transition; structural reform; reversal; stabilization; initial conditions

*The author wishes to thank without further implications Bas van Aarle, Tom Van Ourti and the participants at a BOFIT seminar and two anonymous referees. 


\section{Introduction}

Since the start of the reform process in the early 1990s, economic performance has differed widely among the countries of Central and Eastern Europe (CEE), the Baltic States (BAL) and the other countries of the Former Soviet Union (FSU). Several essential elements of the transition to a market economy are described in Kornai (1994): the move from a sellers' to a buyers' market by price liberalization and trade and foreign exchange liberalization, and the enforcement of a hard budget constraint by means of privatization, elimination of subsidy programs, and the creation and liberalization of a financial market. Blanchard (1997) adds restructuring within surviving firms and reallocation of resources from old to new activities to this list. At the outset of transition it was generally expected that output would fall, but the allocational efficiency of the newly installed market mechanism would quickly boost these economies to high growth rates. Figure 1 illustrates how wrong these expectations were. At the extreme, Stiglitz (1999) argues that the explanation goes as deep as a misunderstanding of the foundations of a market economy as well as a misunderstanding of the basics of institutional reform processes.

$<$ insert figure $1>$

Numerous empirical studies attempted to explain the variation in economic performance. Most studies conclude that three categories of explanatory variables can account for the cross-country differences in output paths: macroeconomic stabilization, structural reform, and initial conditions. Macroeconomic stabilization in the form of lowering inflation rates, often achieved by means of a fixed exchange rate regime and by reducing budget deficits, is found to be conducive to economic growth. Although initial conditions may account to a substantial degree for the variation in economic performance at the start of transition, recent panel data studies conclude that their importance diminishes over time. The effect of reform in the 'standard' empirical framework, a system with real output growth and reform as endogenous variables, is non-linear. Reform has a robust, positive lagged effect (a 'stock' effect), while its current impact is negative or insignificant. If negative, it can be tought of as an adjustment cost. E.g. in the presence of sector-specific knowledge and machinery, the transfer of labour and capital from one industry to another due to new price signals is likely to require an adjustment cost.

This paper adds to this literature by explicitly paying attention to the effect of backtracking in reform. Backtracking in reform or a reform reversal is defined as a downgrading in the level of our average reform indicator. Our reform indicator (RI) is calculated in a standard way as a weighted average of the levels of the transition indicators developed by the European Bank for Reconstruction and Development (EBRD). The indicator reflects the average policy stance with respect to price liberalization, trade and foreign exchange liberalization, privatization, restructuring and financial market reform. Using the definition above, we obtain 21 reversals upon a total of 237 observations. The reversals 
are documented in the appendix. Reversals should thus not be considered as coincidental outliers, but should rather be adressed in the empirical framework. Especially since the non-linear effect of reform in the standard empirical framework implies that -ceteris paribus- a reversal is counterintuitively associated with a short lived positive, or at best an insignificant (but positive) effect. Only two to three years after the reversal occurred its cumulative contribution to growth becomes negative. This also runs contrary to most theoretical models that assume reversal costs. These costs are even attributed a prominent role: Roland (2000) argues that the presence of reversal costs is crucial for gradualist strategies to be preferred over big bang strategies when aggregate uncertainty is taken seriously (what will be the outcome of transition?). If there are no reversal costs, big bang strategies are always optimal because there are no costs of learning and thus there is never an advantage to early reversal.

This paper tests whether we can observe a macroeconomic cost of a reversal, or more specifically: is there an immediate negative impact on real output growth. To this end we estimate a system that explicitly takes the impact of reversals into account. The system's specification, with real output growth and reform as endogenous variables, is comparable to specifications found in the recent literature (see e.g. Falcetti et al. (2002)). Results confirm earlier findings with respect to initial conditions and stabilization and the non-linear effect of reform. With respect to the reversals, we find that a reversal generates an immediate negative contribution to real output growth. The contribution of e.g. the average value of a reversal to the growth rate is $-2.65 \%$-points. Further results suggest that a reversal is more harmful if a country achieved a higher level of the reform indicator. A reversal (of average magnitude) costs up to $3 \%$-points more in growth terms when it occurs at a high level than when it occurs at a low level. Solving the system dynamically replicates the catching up in growth terms on average of FSU-countries with CEE-countries since their respective output troughs. It also illustrates the fact that the reform process is stalling. During the first years of transition a lot of reform was implemented, but further progress later in transition seems limited.

The paper is organized as follows. Section 2 discusses the empirical literature and shows that a reversal results in a short lived positive effect or at best an insignificant (but positive) effect in the standard empirical framework. In section 3 we dicuss reform reversals and reversal costs within the theoretical literature on reform policy. Section 4 deals with data and presents the empirical framework, section 5 presents empirical results and the implied growth effects of reversals. Finally, section 6 concludes. 


\section{Empirical Analysis of Output Growth: The Literature}

Empirical work that tries to explain output performance in transition countries focuses on the impact of three categories of variables: initial conditions, structural reform, and macroeconomic stabilisation. In the literature there is a general agreement that initial conditions do matter, but to which extent they influence macroeconomic performance is more controversial. Their importance seems to depend on the type of study. Falcetti et al. (2002) show that there is a striking difference in the dominant role that initial conditions seem to play in explaining cross-sectional variation in growth performance and the less prominence accorded to them in panel data studies. E.g. Popov (2000) attributes a prominent impact to initial conditions. In Popov (2000) and Krueger and Ciolko (1998) the inclusion of initial conditions even renders the impact of structural reform insignificant. However panel data studies such as Berg et al. (1999) and Falcetti et al. (2002) explicitly allow the impact of initial conditions to fade out as transition progresses. They find that initial conditions were very important in explaning the variation in economic performance at the start of transition, but their impact has diminished over time.

Macroeconomic stabilization in the form of lowering inflation rates, often achieved by means of a fixed exchange rate regime and by reducing budget deficits, is generally agreed to be conducive to growth (e.g. De Melo et al. (1996), Fischer et al. (1996a,b)). In line with more general evidence (cf. Bruno and Easterly (1998)), reducing inflation from very high to more moderate levels (say 40-50\%) was even identified as a necessary condition for growth recovery (Fischer et al. (1996a) and Loungani and Sheets (1997)). Fischer et al. (1996b) argue that inflation cannot be reduced below 40-50\% p.a. without adversely affecting growth, unless key structural reforms have been implemented. On the other hand, Åslund et al. (1996) argue that price stabilization is a necessary but not sufficient condition for reform to be effective. Berg et al. (1999) point to possible endogeneity problems of inflation. The use of instrumental variables does not alter their results significantly, however. Extensively using model selection tools, they find furthermore that the positive impact of stabilization is not that robust. They do find that at least one macroeconomic policy variable always rejects exclusion. The fiscal balance proved more difficult to reject than inflation.

The ability of transition countries to reallocate resources toward their best use and to establish institutions to that end has been a major determinant of transition patterns (De Melo et al. (2001)). The idea is that the closer a country is to a market economy, the more it benefits from the market's growth generating (allocational) efficiency. While most academics more or less agreed upon the contents of reform, the speed of reform was heavily debated: there were proponents of a big-bang strategy (see e.g. Sachs (1993)), while others advocated a more gradual approach (see e.g. Dewatripont and Roland (1992a, 
b)). As transition progressed, data for empirical tests became available. De Melo et al. (1996) constructed an aggregate liberalization index (LI) measuring achieved reform in different areas. Numerous studies ${ }^{1}$ analyzed the impact of the cumulative liberalization index (CLI) on output growth, interpreting it as a measure for the speed of reform. Most of these studies find a significant positive impact of the CLI on economic growth, interpreting this as evidence in favour of a big bang strategy. Heybey and Murrell (1999) criticize the use and interpretation of the CLI as indicator of 'speed'. Since in a given year the CLI is calculated as the sum of the levels of the annual LI in all previous years, any (advanced) market economy would outscore the transition countries with respect to reform speed even if no reform took place. Heybey and Murrell (1999) define the speed of reform as the average growth in the level of the liberalization index (LI) since the start of transition. In their cross-section estimation the speed of reform has no significant impact. This reflects two opposing effects: the gains from liberalization of entry of new firms and the cost of dislocation in the existing state sector. They expect the former to start to dominate as transition progresses. This is in line with Berg et al. (1999) who show that a smaller negative impact of liberalization on state sector performance is offset by a larger positive impact on private sector growth.

Until recently most studies assumed reform to be exogenous to growth, implying a one-way causation from reform to growth. Clearly, the failure to take into account the feedback of growth to reform and the impact of initial conditions on reform will bias the estimated impact of reform on growth. Because policy choices result from a politically constrained process affected by economic variables, they simply cannot be considered as exogenous decisions (Campos and Corricelli (2002)). To tackle this problem Wolf (1999) uses an instrumental variables approach. Heybey and Murrell (1999) propose estimating a system with both growth and the speed of reform as endogenous variables. Falcetti et al. (2002) use a comparable system in a panel framework, but focus on growth and the level of reform as endogenous variables. The use of panel data also allows to test for dynamic effects of reform. Selowsky and Martin (1997) and De Melo et al. (2001) find a robust positive impact of the lagged CLI and a negative impact of the current CLI, reflecting an adjustment cost. Wolf (1999) and Falcetti et al. (2002) find a significant impact of the lagged LI, while the impact of current reform is insignificant. In general terms, the level of reform, measured by LI, enters a growth equation in the following way: $\alpha L I_{t}+\beta L I_{t-1}$, where the expectation is that $\alpha<0, \beta>0$ and $|\alpha|<\beta$. The negative effect of current reform reflects an adjustment cost. The positive effect of lagged reform ('stock' effect) builds upon the idea that the closer to a market economy, the more the economy can benefit from the market mechanism (in particular better resource allocation), leading to improved growth performance. The expectation is that eventually the stock effect dominates when it has reached a sufficiently high level $(\sim|\alpha|<\beta)$. Rewriting this expression as $\alpha \Delta L I_{t}+(\alpha+\beta) L I_{t-1}$, it

\footnotetext{
${ }^{1}$ See e.g. De Melo et al. (2001), Åslund et al. (1996), Fischer et al. (1996a,b) and Selowsky and Martin (1997).
} 
is nicely interpretable as a policy change $\left(\Delta L I_{t}\right)$ that affects growth negatively and the policy stance $\left(L I_{t-1}\right)$ that affects growth positively (recall that $|\alpha|<\beta$ is expected). However with $\alpha<0$ a reform reversal, defined as $\Delta L I_{t}<0$, generates an instantaneous positive growth effect in period $t$, slowing down growth only the following year because of the lower level of the policy stance $\left(L I_{t-1}\right)$. Should the estimate of $\alpha$ be insignificant, then there would be no significant effect on growth the year the reversal occurs. In the empirical part of this paper we address the case of a reform reversal in a system explaining growth and reform simultaneously. The next section discusses the role of a reversal in the theoretical literature on policy (reform).

\section{Reform and Reform Reversals in the Theoret- ical Literature}

In this section the focus is on liberalization policies aimed at structural reform ${ }^{2}$ in order to enhance economic growth and welfare. As in the previous section, this type of reform should be distinguished from macroeconomic policies aimed at economic stability (Rodrik (1996)). The economic growth literature mostly attributes bad growth performance and underdevelopment to inappropriate or 'bad' policies, but unfortunately government policy itself is often treated as exogenous. This leaves open the question why some societies have managed collectively to adopt good policies where others failed to do so. The experience of developing countries in the 1980s made it clear that good economic policy advice requires a good understanding of the political economy of policy formation (see e.g. Rodrik $(1993,1996)$ and Tommasi and Velasco (1996)). According to Robinson (1998) a useful approach to understanding policy determination is to think in terms of a model where individuals in society can form coalitions depending on their induced preferences over policy. Since development is not pareto improving, those who lose have an incentive to oppose to it. If the latter are a politically powerful group "bad policies" rather than a compensation seem to occur. Without compensating schemes a trade-off is created between distribution and efficiency, bad policies then get chosen because of their distributional effects. Why is political control then so little used to compensate for disadvantageous distributional consequences of an efficiency enhancing policy? Robinson (1998) offers two possible reasons. The first is the commitment problem: implementing good policies to increase investment may not stimulate the economy because the politically powerless fear future expropriation of returns. Second, adopting good policies might change the future political equilibrium. If the current governing coalition is endangered by the future equilibrium, this may restrain them from adopting good policies.

The large-scale reform process in the former socialist countries only strengthened the idea that good economic advice requires a good understanding of policy formation. The embarkment on the transition to a market economy gave rise to

${ }^{2}$ Price and trade liberalization, privatization and restructuring, financial sector reform, ... 
further modelling of the political economy of policy formation. In the transition context, the contents of reform was more or less agreed upon, but the speed (and sequencing) were heavily debated. Most transition policy models focus on the choice of the appropriate strategy: big bang or gradualism. Next, I discuss some models and point to the role of reversal (costs) in them.

Fernandez and Rodrik (1991) discuss (resistance to) the implementation of large scale reform when the distribution of gains and losses from reform is uncertain (individual specific uncertainty). In a dynamic setting they show that reform with an ex ante expected negative outcome is never voted in, even if a majority of voters would benefit ex post. Reforms that benefit a majority of voters both ex ante and ex post are voted in and maintained. Reforms with ex ante positive outcomes, but ending up hurting a majority ex post are voted in at the outset and reversed in the next period if the expected first period benefits exceed the reversal costs (a sunk investment cost). The result is the so-called status quo bias: reforms that are initially rejected continue to be so (because no new information is revealed by adopting them) and some reforms that were accepted are reversed in the second period. The model implies that a reversal is known to occur with certainty since it is decided upon together with the acceptance of the reform. ${ }^{3}$ Clearly if there were no reversal costs, all reforms with $e x$ ante expected positive outcomes would be adopted. Higher reversal costs will -ceteris paribus- result in less temporary reform. The reason for the reversal to be known on beforehand is the absence of aggregate uncertainty: the outcome of the reform is known, solely its distribution is uncertain.

Rodrik (1995) considers a model of sectoral reallocation (from a low-productivity state sector to a high-productivity private sector) to analyze the dynamics of preferences over economic policy. I.e. the choice of the level of a subsidy to state-sector workers financed by a tax on private-sector workers. It is shown that if a reform (i.e. a decrease of the subsidy to allow faster development of the private sector) is opposed at the outset by state-sector workers but is embarked on nonetheless, the reform may (depending on parameter settings) eventually gain support for continuation from state-sector workers. Should there be a vote between continuing the transition or returning to the status-quo, a reversal would thus only occur during the early stages of transition. On the other hand, in some parameter settings radical reform (big bang) can be endorsed by state-sector workers at the outset of transition. ${ }^{4}$ In this case, state-sector workers' preferences will unambiguously change to a slow-down of the transition process. Whether a reversal actually occurs depends on how preferences are transformed in policy, i.e. on the political power of state-sector workers.

\footnotetext{
${ }^{3}$ If the reform has an ex ante expected positive outcome, but ends up hurting a majority ex post, agents must choose between a status quo and a temporary reform.

${ }^{4}$ Radical reform takes state-sector workers prefer no subsidy to allow the priavte sector to expand as rapidly as possible. This is the case when only a small subsidy is feasable, the costs then outweigh the benefits of the small subsidy to workers employed in the state-sector. The associated costs are twofold: a subsidy reduces both the probability of finding a job in the private sector and the future earnings after finding a job in the private sector.
} 
Dewatripont and Roland (1992a, b) deal with the political viability of unpopular policies. They analyze an agenda-setting government that wants to shrink the size of the state sector but is subject to political constraints (unanimity rule and majority rule). ${ }^{5}$ Gradualism can emerge as a sequentially optimal reform path when the budgetary cost of reform is a significant determinant of optimality. Since the government can use threats to gain support from groups in society for a policy that hurts these groups' interests, democracy should not be overestimated as a threat to transition. ${ }^{6}$ As long as the government's degree of legitimacy is sufficient to have full control over the agenda, it can put through its policies.

Large scale reforms do often not only involve individual uncertainty, but also a great deal of aggregate uncertainty as well. Specifically in the context of transition countries it is far from clear whether the outcome will necessarily be a copy of the West German miracle. In Dewatripont and Roland (1995) the role of a reversal is based on the idea of aggregate uncertainty: it can be more advantageous to return to the conservative platform in case of a negative aggregate outcome of market-oriented reform. The cost of a reversal is then the expected pay-off of reversing the reform and returning to the conservative platform. Since reversing a big bang to the conservative platform requires a larger amount of reform to be undone, the reversal costs are higher than in the gradualist case. Comparing big bang and gradualist strategies, these high reversal costs associated with a big bang are often considered an advantage $e x$ post since they reduce the reversibility. Considering the possibility of a negative aggregate outcome, the high reversal costs may make the big bang strategy politically unfeasible however. Gradualism on the other hand makes reforms easier to start because the cost of reversing after partial uncertainty resolution is lower. In the presence of aggregate uncertainty gradualism allows flexible approach to reforms with smaller costs of trial and error. Strong complementarity of reforms does not necessarily weaken the case for gradualism, but may on the contrary, give it an additional advantage by building constituencies for further reform. If initial reforms have been a success people are more willing to accept less popular reforms. More generally, Murrell (1992) makes an argument for gradualism in the spirit of evolutionary economics. The process rather than the (final) goal is emphasized. Since there is little to say about the end point of transition (because of aggregate uncertainty), the focus should be on learning about possible outcomes through the transition strategy chosen. Roland (2000) also discusses the politics of reform under uncertainty. In the different models of transition he presents (models incorporating political constraints, aggregate uncertainty and complementarities) the presence of reversal costs is crucial for gradualism to dominate a big bang strategy. If there are no reversal costs, there

\footnotetext{
${ }^{5}$ The model is tailored to restructuring, but leaves out other important phases of transition (privitization, price liberalization, ...). The analysis is based on informational asymmetries.

${ }^{6}$ This refers to a reform paradox: it is often thought that it takes strong or even authoritarian leadership to implement reforms aimed at improving the well-being of a large majority of the population.
} 
is no advantage to early, low cost reversal. Roland (2000) thus points to the crucial role of reversal costs as costs of learning to be weighted against the benefits of learning: "If reversal costs are important for large-scale experiments, uncertainty will lead to slowing down reform. Otherwise uncertainty can lead to accelerating it."

Though it is not always clear in what terms pay-offs and reversal costs should be interpreted in the models, reversals do always cost. Given the rather odd implication of an instantaneous positive or no growth effect in the standard empirical framework, it is interesting to test whether backtracking in reform has affected real output growth during transition.

\section{Data and Empirical Framework}

First of all it is widely known that data on transition countries ${ }^{7}$, especially those from early in the transition phase, are qualitatively not comparable to western country data. The decline in output is believed to be overestimated, because newly emerging activities were inadequately captured and existing firms had an incentive to underreport output and sales to avoid taxes (see Berg et al. (1999) or Havrylyshyn et al. (1998) for further details). Studies that use adjusted GDP data (based on electricity consumption e.g.), do not find considerable differences (cf. Selowsky and Martin (1997)).

Second, our aggregate reform index $(R I)$ is constructed as a weighted average of eight transition indicators as found in the EBRD's Transition Report. (see also De Melo et al. (1996)). These indicators reflect the progress of reform with respect to $i$ ) price liberalization (weight 0.3 ), ii) trade and foreign exchange liberalization (weight 0.3 ), and iii) privatisation, restructuring and financial market reform (weight 0.4). The latter itself is the unweighted average of the following transition indicators: small-scale privatisation, large-scale privatisation, enterprise reform, competition policy, banking sector reform, and reform of non-banking financial institutions. ${ }^{8}$ Clearly, when interpreting results one should bear in mind that these are subjective indices rather than directly observable variables. A reversal is then defined as a decrease in this aggregate reform index, i.e. $R I_{t}-R I_{t-1}<0$. In our sample covering about ten years of transition experience for 25 countries ( 237 observations), we have 21 reversals in the aggregate index. The Appendix contains a detailed description of these reversals, based upon the notes in the statistical appendices to the EBRD's Transition Report.

Third, all data were rearranged in 'transition timing'. In order to identify common elements across countries of the post-communist economic cycle, we have to take into account the cycle's different starting points. Transition year 1 $(t)$ is then defined as the year in which communism and central planning were definitively abandoned. This is 1990 for Croatia, Hungary, FYR Macedonia,

\footnotetext{
${ }^{7}$ See the appendix for data sources.

${ }^{8}$ See appendix for further details.
} 
Poland and Slovenia; 1991 for Albania, Bulgaria, the Czech and Slovak Republic and Romania. For the Baltic States and the countries of the Former Soviet Union 1992 is taken to be the first year of transition.

Fourth, since both reforms and growth follow a clear time pattern, it is possible that the correlation between them is spurious. We control for the common time pattern by introducing a uniform quadratic time trend. In addition country specific fixed effects are used rather than the initial condition clusters. The correlation between them is however fairly high ( $c f$. infra). Time-varying effects of the initial conditions are accounted for, since their impact can be expected to decrease as transition progresses. We use the initial condition clusters of De Melo et al. (2001). By means of a principal component analysis they reduced a set of eleven conditions to two clusters. First, an index of macroeconomic distortions at the beginning of transition and unfamiliarity with a market environment $(I C 1)$ and, second, an index of the level of socialist development and associated distortions prior to transition $(I C 2)$. The clusters express cross-country differences and the values of $I C 1$ and $I C 2$ do not have a direct interpretation. In general, the macroeconomic distortions were much larger in FSU-countries and the Baltic States than in CEE-countries, the picture on overall development is less clear.

Finally to deal with the endogeneity bias, we resort to a 3SLS estimation of the following system where growth and reform are jointly determined and affect one another:

$$
\begin{aligned}
\Delta G D P_{i, t}= & \alpha_{0}+\alpha_{i}+\alpha_{1} R I_{i, t}+\alpha_{2} R I_{i, t-1}+\alpha_{3} \Delta R I_{i, t} D_{i, t} \\
& +\alpha_{4} t+\alpha_{5} t^{2}+\alpha_{6} t I C_{1}+\alpha_{7} t I C_{2}+\alpha_{8} S T A B_{i, t}+\varepsilon_{i, t} \\
R I_{i, t}= & \beta_{0}+\beta_{i}+\beta_{1} \Delta G D P_{i, t}+\beta_{2} \Delta G D P_{i, t-1}+\beta_{3} F S_{i, t} \\
& +\beta_{4} t I C_{1}+\beta_{5} t I C_{2}+\eta_{i, t}
\end{aligned}
$$

System (1) is closely related to the panel specification in Falcetti et al. (2002). If $\alpha_{3}$ is set to zero, we obtain the 'standard' empirical framework. Real GDP-growth (domestic currency) is related to a constant, a country fixed effect, a quadratic time trend, $I C 1$ and $I C 2$ multiplied by a linear time trend, a stabilization variable, current and lagged reform and finally a reversal variable constructed as $\Delta R I_{i, t} D_{i, t} . D_{i, t}$ is a dummy variable that takes the value 1 if a reversal occurrs and 0 otherwise, $\Delta R I_{i, t}$ is the change in the aggregate reform indicator, a bigger reversal is thus assumed to have a larger effect. As stabilization variable we choose the fiscal balance. Campos and Corricelli (2002) argue that inflation is rather a policy result, whereas the fiscal balance refers more to the policy itself. This is in line with Fischer et al. (1996b) who show that smaller fiscal deficits are especially important in reducing inflation. An empirical argument is given by Berg et al. (1999) who show that the fiscal balance is more difficult to reject than inflation (cf. supra) in modelling transition countries' output paths. Falcetti et al. (2002) also use the fiscal balance as stabilization 
proxy, the use of different stabilization measures does not significantly affect results.

\section{Empirical Results}

Table 1 presents the results of the 3SLS estimation of system (1). As a benchmark case, the first column presents the estimates of (1) without the reversal. Results comfirm the results of Falcetti et al. (2002), who use a closely related specification. The impact of the current level of reform is negative and insignificant, whereas the impact of lagged reform is positive and strongly significant. As measure of stabilization the fiscal balance is correctly signed and significant. An improvement in the fiscal balance ('stabilization') leads to a better growth performance. The common time pattern, identified by the quadratic time trend is also significant and accounts for part of the U-shape. Turning to the initial conditions, the level impact of $I C 1$ and $I C 2$ are reflected in the country fixed effects. In particular the correlation of the country effects with IC1 in the $\triangle G D P$-equation is as high as -0.92 , the correlation with $I C 2$ is only 0.10 . As for the time-varying impact, only $I C 1$ has a significant time-varying impact. Since the values of $I C 1$ range from -1.47 to +1.27 and a bigger value refers to worse initial conditions, the over time increasing impact reflects that countries which were worse of at the start of transition are catching up later (converging effect). There is no evidence of a time-varying impact of $I C 2$. Turning to the reform equation we observe a strongly significant positive impact of contemporaneous growth on the level of reform. The impact of lagged growth is negative but smaller in absolute value and not significant. With respect to the initial conditions, again only $I C 1$ has a significant time-varying impact. The impact is negative in this case, implying a divergence between countries with good and bad (negative and positive) initial conditions. IC 1 thus continues to influence growth negatively through its impact on reform, while the direct impact is diminishing over time. Finally the freedom status has the expected effect, i.e. countries with more civil liberties achieve a higher level of reform.

Column [2] explictly introduces the reversal concept. Coefficients are fairly stable both with respect to magnitude and significance. The coefficients on current and lagged reform in the $\triangle G D P$-equation increase in absolute value; current reform remains insignificant. The reversal parameter itself is positive and significant ( $z$-statistic 1.88). Columns [3] and [4] investigate the sensitivity of the estimates to the stabilization proxy. Using inflation, or a combination of current and lagged inflation, results in a further increase in the absolute value of the coefficients on current and lagged reform, the reversal coefficient increases as well. The reversal coefficient is significant at the 5\%-level.

$<$ insert table 1 around here $>$

Concentrating solely on the $\triangle G D P$-equation, the effect of a reversal is presented in table 2. Row headings give the amount of reform reversed. Column 
headings give the 'reversal timing', where $r$ is the year a reversal occurs. The table entries then give the cumulated effect of a reversal up to year $r+n$. This effect is calculated as follows: first current and lagged reform in the $\Delta G D P$-equation of (1) are rewritten as $\alpha_{1}\left(R I_{t}-R I_{t-1}\right)+\left(\alpha_{1}+\alpha_{2}\right) R I_{t-1}$ $+\alpha_{3} \Delta R I_{i, t} D_{R I, i, t}$. This allows for a distinction between an immediate impact $\alpha_{1} \Delta R I_{i, t}+\alpha_{3} \Delta R I_{i, t} D_{R I, i, t}$, and a 'long run' impact $\left(\alpha_{1}+\alpha_{2}\right) R I_{i, t-1}$ in all successive periods. In this way a reversal is considered as 'lost forever', i.e. in every successive period the policy stance could have been higher if no reversal had occurred. The normal entries in table 2 are then calculated as $\alpha_{1}^{[1]} \Delta R I_{t}+n\left(\alpha_{1}^{[1]}+\alpha_{2}^{[1]}\right) \Delta R I_{t}$ where $n$ is the number of years since a reversal occurred $^{9}$ and the parameters are taken from [1] $\left(\alpha_{3}=0\right) . \alpha_{1}^{[1]} \Delta R I_{t}$ is the immediate impact of a reversal at $r ; n\left(\alpha_{1}^{[1]}+\alpha_{2}^{[1]}\right) \Delta R I_{t}$ reflects the idea that the stock of reform $R I_{t-1}$ is $\Delta R I_{t}$ lower than it could have been in every year following the reversal. The entries are not growth rates, but the contribution in \%points of a reversal to the growth rate. As can be seen from the table, a reversal is associated with a short lived positive effect, lasting two periods. The average reversal of -0.155 increases the growth rate with $0.8 \%$-points. From $r+2$ onwards the lower stock starts to dominate and the overall effect of the reversal becomes negative. The bold entries are calculated as $\alpha_{1}^{[2]} \Delta R I_{t}+n\left(\alpha_{1}^{[2]}+\alpha_{2}^{[2]}\right) \Delta R I_{t}$ $+\alpha_{3}^{[2]} \Delta R I_{i, t} D_{R I, i, t}$, where parameters are now taken from column [2] of table 1 . In this case the immediate effect at $r$ is $\alpha_{1}^{[2]} \Delta R I_{t}+\alpha_{3}^{[2]} \Delta R I_{i, t} D_{R I, i, t}$. A reversal now has an immediate negative impact in period $r$. E.g. the contribution of the average reversal of -0.155 to the growth rate is $-2.65 \%$-points. The difference in the immediate impact on real GDP growth in period $r$ obtained by taking into account the occurrence of a reversal ranges from \pm 0.5 to $\pm 15 \%$-points, depending on the magnitude of the reversal. Since $\alpha_{1}^{[1]}+\alpha_{2}^{[1]}>\alpha_{1}^{[2]}+\alpha_{2}^{[2]}$, the cumulated effect based on [1] will eventually catch up with the one based on [2]. This takes however until $r+14$ to happen. Neglecting the insignificant current effect of reform does not alter the general observation that at $r$, the time the reversal occurs, [2] implies a significant negative impact, while in [1] the growth rate is not significantly influenced.

$<$ insert table 2 around here $>$

Column [5] in table 1 tests the idea that a reversal is more harmful (in growth terms) if a country achieved a more advanced level of reform. ${ }^{10}$ To test this idea the reversal dummy is multiplied both with the reversal $\left(\Delta R I_{t}\right)$ and with the stock of reform $\left(R I_{t-1}\right)$. The coefficient on this variable is significant at the $5 \%$ level ${ }^{11}$ and is correctly signed. All other coefficients are close to the ones in the

\footnotetext{
${ }^{9}$ e.g. at $r+2, n=2$; at $r, n=0$.

${ }^{10}$ E.g., since a country at a more advanced level is likely to attract more foreign investment, and since a reversal is likely to cause a decrease in foreign investment and possibly even a withdrawal of foreign investment, the effect is likely to be larger since there is more to lose.

${ }^{11}$ Comparing results in [5] with those in [2] (both use the fiscal balance as proxy for stabilization), the z-statistic is considerably higher.
} 
other estimations. The implications for GDP growth rates of a reversal of 0.155 (i.e. the average reversal) are calculated in table 3. Column headings indicate the possible stock of reform at the time the reversal is occurring. The difference between a stock of 1.50 and 4.00 is as high as $3.1 \%$-points. ${ }^{12}$ Comparing table 2 and table 3 , the estimated impact of a reversal without taking the stock into account is about the same as the impact calculated at a value of 3 for the reform index.

\section{$<$ insert table 3 around here $>$}

Since (1) is a dynamic system, we can calculate time paths for $\triangle G D P$ and $R I$, based on values for the exogenous variables and intial values for $R I_{t-1}$ and $\Delta G D P_{t-1}$. Figures 2, 3 and 4 present growth rates, GDP-paths (index $t-1=100$ ) and the reform index for the average transition country (upper left panel), the average CEE country ( $\overline{C E E}$, upper right panel), the average FSU country $(\overline{F S U}$, lower left panel $)$ and the average Baltic state $(\overline{B A L}$, lower right panel). Each figure presents results based on [1] and [5] in table 1, both with a reversal in period $t+2$ of -0.155 (average reversal) and without reversal. For the average transition country the actual values are drawn as well. Both [1] and [5] fit the average of the actual data fairly well. Only from $t+3$ until $t+5$ the growth is on average somewhat underestimated by the model. Concentrating on the effect of the average reversal $(-0.155)$ at $t+2$, figure 2 shows the immediate impact in $t+2$ for [5], whereas [1] does not reveal anything until $t+3$. Turning to figure 3 , the reversal results in a steeper (and earlier) decline for [5] but it catches up with [1] (compare to the no reversal case where [5] starts to outgrow [1] from $t+3$ onwards as well). Finally from figure 4 one can infer that the simulated path of the level of reform is about the same for [1] and [5]. In both cases it takes four years until the reform index reaches its 'no reversal' level (i.e. difference $<0.01)$. The growth losses caused by a reversal ${ }^{13}$ at a comparable level of the reform index are larger than the ones in table 3 , based solely on the $\triangle G D P$-equation. First, because of negative feedback effects from growth to reform and then again from reform to growth. Second, because of the fact that in the absence of a reversal the level of reform increases. This makes the difference between the stock of reform in the reversal and no reversal case larger, which results in a bigger growth loss (cf. the upper left panel in figure 4).

$<$ insert figures 2, 3 and 4 around here $>$

Figures 2, 3 and 4 also allow a comparison between $\overline{C E E}, \overline{F S U}$ and $\overline{B A L}$. Our estimates simulate the largest output fall for $\overline{F S U}$, the smallest one for $\overline{C E E}$ with $\overline{B A L}$ holding the middle between these two. More interestingly,

\footnotetext{
${ }^{12}$ As transition continues, this difference remains constant since in all cases the stock is 0.155 lower than it could have been.

${ }^{13}$ These are calculated by subtracting the simulated path based on [1], respectively [5] with a reversal at $t+2$ from the simulated path based on [1], resp. [5] without a reversal and summing these values to obtain cumulated losses comparable to table 3.
} 
one can infer that $\overline{F S U}$ and $\overline{B A L}$ are catching up with $\overline{C E E}$. This is in line with Fischer and Sahay (2000), who indicate that, since the output troughs, average growth rates in FSU-countries have been higher than in CEE-countries. The CEE-countries show a decreasing growth rate from $t+8$ onwards. This is due to the negative, in time increasing impact of $I C 1$ that starts to dominate the other variables. Figure 4 points to another problem: the reform processes seem to stall. The reform indicator drastically improves during the first years of transition, but further progress later in transition is limited. $\overline{C E E}$ and $\overline{B A L}$ stalled around a level of about 3.4, $\overline{F S U}$ at a level of about 2.7, whereas a score comparable to a market economy would be about 4.3. Piazolo (1999) argues that the initial rapid progress in reform was based on three essentially temporary factors and that further progress requires substantial efforts. First, neighbouring developed economies can be easily used as a guiding example for the first reforms. As transition continues, reform becomes more complicated and developed economies do not serve as clear-cut examples any longer. Second, several interest groups gained strength and formed opposition to further reforms that endangered their position. Third, the public no longer accepts the government pushing through its policy without public consensus, once the initial 'market-euphoria' has been offset by large output declines and a difficult recovery. Requirments for EU accession may be a way to induce some further progress in candidate countries.

\section{Conclusions}

Previous analysis showed that the evolution to a market system is one of the central elements in the transitional phase. The closer to a market system, the more beneficial effects on growth are expected. In the literature it is found that current reform affects growth negatively, while lagged reform affects growth positively and eventually starts to dominate. We showed that the nonlinear effect of reform in the standard empirical framework, a system with real output growth and reform as endogenous variables, implies that -ceteris paribusa reversal generates a short-lived positive, or at best an insignificant, contribution to growth. A reversal is defined as a downgrading in the level of the reform indicator. We measure reform as a weighted average of the transition indicators of the EBRD. The indicator reflects the policy stance with respect to price liberalization, trade and foreign exchange liberalization, privatization, restructuring and financial market reform.Our sample contains 21 reversals upon 237 observations, pointing to the relevance of reversals during transition. From a theoretical point of view, the importance of reversals lies in the existence of reversal costs. These costs are crucial for gradualist strategies to dominate a big bang strategies in the presence of aggregate uncertainty.

In a simultaneous equation system with real GDP growth and the level of reform as endogenous variables, we explicitly introduced a test for the effect of a reform reversal. Generally, earlier findings are confirmed. With respect to the reversal case, our results suggest that a reversal generates an immediate negative 
contribution to real output growth, contrary to the implied positive effect in the standard framework. The immediate contribution of e.g. a reversal of average magnitude to the growth rate is $-2.65 \%$-points. In the standard framework the same reversal increases the growth rate with $0.8 \%$-points. Only two years later the lower stock of reform starts to dominate and the overall effect of the reversal becomes negative. A further tests suggest that a reversal is more harmful (in growth terms) if a country achieved a higher level of the reform indicator. A reversal of average magnitude that occurs at a high stock costs about 3\%-points extra in growth terms compared to the same reversal at a low stock. Solving the model dynamically replicates the catching up in average growth terms of FSU-countries with CEE-countries. It also nicely illustrates the fact that the reform process is stalling. During the first years of transition a lot of reform was implemented, but further progress later in transition seems limited.

The results in this paper demonstrate the importance to think about reversals and to take them into account. A detailed study of the causes of reversals is left for further research. Since the models discussed in section 3 point to the interaction of reform and politics, a good starting point can be an analysis of the political situation at the time of the reversal. E.g. Tommasi and Velasco (1996) give some descriptive evidence of the impact of election outcomes on the subsequent reform strategy. For a sample of 16 higly-studied reforming countries (including three CEE countries) they report election outcomes and their impact upon the reform process. In only one out of the sixteen countries reforms were reversed by the new governement, in a small share of countries a change in political circumstances led to a slowdown in reform and in several countries reforms were continued even after the opposition to the initial reforming government came to power. Clearly, their starting point is an election outcome, while here the reversals themselves rather should be taken as starting point. 


\section{References}

Åslund, A., Boone, P. And Johnson, S. (1996), How to Stabilize: Lessons from Post-Communist Countries, Brookings Papers on Economic Activity, no.1, pp. 217-91

Berg, A., Borensztein, E., Sahay, R. and Zettelmeyer, J. (1999), The Evolution of Output in Transition Economies: Explaining the Differences, IMF Working Paper, WP/99/73, 81p.

Blanchard, O. (1997), The Economics of Post-Communist Transition, Clarendon Lectures in Economics, Oxford University Press, 149p.

Bruno, M. and Easterly, W. (1998), Inflation Crises and Long Run Growth, Journal of Monetary Economics, vol. 41, p.3-26

Campos, N., and Coricelli, F. (2002), Growth in Transition: What We Know, What We Don't, and What We Should, Journal of Economic Literature, Vol. $X L$, pp.793-836

De Melo, M., Denizer, C. And Gelb, A. (1996), From Plan to Market: Patterns of Transition, World Bank Economic Review, vol. 10(3), pp. 397424

De Melo, M., Denizer, C., Gelb, A. and Tenev, S. (2001), Circumstance and Choice: the Role of Initial Conditions and Policies in Transition Economies, World Bank Economic Review, vol. 15(1), pp. 1-31

Dewatripont, M. and Roland, G. (1992a), Economic Reform and Dynamic Political Constraints, Review of Economic Studies vol. 59(4), p.703-30

Dewatripont, M. and Roland, G. (1992b), The Virtues of Gradualism and Legitimacy in the Transition to a Market Economy, Economic Journal, vol. 102(411), .p.291-300

Dewatripont, M. and Roland, G. (1995), The design of reform packages under uncertainty, American Economic Review, Vol. 85(5), p.1207-1223

European Bank for Reconstruction and Development, EBRD Transition Report, London: EBRD, various issues

Falcetti, E., Raiser M. and Sanfey, P. (2002), Defying the Odds: Initial Conditions, Reforms, and Growth in the First Decade of Transition, Journal of Comparative Economics, vol. 30, pp. 229-250

Fernandez, R., And Rodrik, D. (1991), Resistance to Reform: Status Quo Bias in the Presence of Individual-Specific Uncertainty, American Economic Review, vol. 81(5), pp.1146-55

Fisher, S. And Sahay, R. (2000), The Transition Economies after Ten Years, IMF Working Paper WP/00/30, 43p. 
Fisher, S., Sahay, R. And Végh, C. (1996a), Economies in Transition: The Beginnings of Growth, American Economic Review Papers and Proceedings, vol. 86(2), pp. 229-33

Fisher, S., Sahay, R. And Végh, C. (1996b), Stabilization and Growth in Transition Economies: The Early Experience, Journal of Economic Perspectives, vol. 10, no. 2, p.45-66

Freedom House, Nations in Transit Report, various issues

HaVrylyshyn, O., Izvorski, I. and van Rooden, R. (1998), Recovery and Growth in Transition Economies 1990-97: A Stylized Regression Analysis, IMF Working Paper, WP/98/141, 37p.

Heybey, B. And Murrell, P. (1999), The Relationship between Economic Growth and the Speed of Liberalization during Transition, Journal of Policy Reform, vol. 3(2), pp. 121-37

Kornai, J. (1994), Transformational Recession: The Main Causes, Journal of Comparative Economics, vol. 19, pp.39-63

Krueger, M. And Ciolko, M. (1998), A Note on Initial Conditions and Liberalization during Transition, Journal of Comparative Economics, vol. 26, pp. 718-34

Loungani, P. And Sheets, N. (1997), Central Bank Independence, Inflation and Growth in Transition Economies, Journal of Money, Credit and Banking, vol. 29(3), pp.381-399

Murrell, P. (1992), Conservative Political Philospohy and the Strategy of Economic Transition, East European Politics and Society, vol. 6(1), pp. 3-16

Piazolo, D. (1999), Growth Effects of Institutional Change and European Integration, Economic Systems, vol. 23(4), pp. 305-330

Popov, V. (2000), Shock Therapy versus Gradualism: The End of the Debate (Explaining the Magnitude of the Transformational Recession), Comparative Economic Studies, vol. XLII(1), pp. 1-57

Robinson, J. (1998), Theories of Bad Policies, Journal of Policy Reform, vol. 2(1), pp.1-46

Rodrik, D. (1993), The Positive Economics of Policy Reform, American Economic Review Papers and Proceedings, vol. 83(2), pp. 356-61

RodrIK, D. (1995), The Dynamics of Political Support for Reform in Economies in Transition, Journal of the Japanese and International Economies, Vol. 9, pp.403-25 
Rodrik, D. (1996), Understanding Economic Policy Reform, Journal of Economic Literature, Vol. XXXIV, pp.9-41

Roland, G. (2000), Transition and Economics: Politics, Markets and Firms, Cambridge MIT Press

Sachs, J. (1993), Poland's Jump to the Market Economy, Cambridge MIT Press

Selowsky, M. and Martin R. (1997), Policy Performance and Output Growth in the Transition Economies, American Economic Review Papers and Proceedings, vol. 87(2), pp. 349-53

Stiglitz, J. (1999), Whither Reform? Ten Years of the Transition, paper presented at the World Bank Annual Conference on Development Economics, Washington

Tommasi, M. and Velasco, A. (1997), Where are we in the Political Economy of Reform, Journal of Policy Reform, vol. 1(2), pp.187-238

Wolf, H. (1999), Transition Strategies: Choices and Outcomes, Princeton Studies in International Finance, no. 85 


\section{Appendix: Reform reversals in transition countries}

The description of the reversals in this appendix is based upon the country assessments which can be found in the various issues of the EBRD's Transition Report. A reversal is defined as a downgrading of a country's score on our reform indicator, which is a weighted average of eight transition indicators as found in the EBRD's Transition Report. This average indicator (see also De Melo et al. (1996)) is constructed as a weighted average of three subindexes reflecting the progress of reform with respect to $i$ ) price liberalization (weight 0.3 ), ii) trade and foreign exchange liberalization (weight 0.3 ), and iii) privatisation, restructuring and financial market reform (weight 0.4). The latter itself is a simple average of the following EBRD indices: small-scale privatisation, largescale privatisation, enterprise reform, competition policy, banking sector reform, and reform of non-banking financial institutions. The EBRD reports values on these indices. A single index can take values between 1 and 4.3 with steps of about $\frac{1}{3}$ ( + and - signs in earlier editions of the Transition Report). This implies that a reversal in our context can be due to a reversal in one or more subcategories; or that a small reversal in one subcategory can be compensated for by progress in other subcategories. The latter is the case in Azerbaijan (1999, large scale privatisation), Latvia (1997, enterprise reform), Lithuania (1997, enterprise reform), and Romania (1997, banking sector reform).

- Belarus 1996 - index private entry in markets (large scale privatisation, banking sector reform)

Already in 1993 Belarus launched a privatisation programm for large stateowned enterprises. In 1996 however, only $20 \%$ of the programm's total number of enterprises had been 'transformed' into joint stock-companies, in which the the government initially owns $100 \%$ of the shares. Genuine privatisation with majority ownership and decision-making powers transferred to private investors had not really been taking place. The 1996 privatisation programm stated that shares were to be sold to the population for vouchers that had been distributed in 1994. Early 1996 registration of enterprises was suspended, however, so that a change in the ownership structure could not be registered. This measure effectively suspended the privatisation process. Additionally new companies could also not be registered any longer.

In 1996 the four largest banks were still controlled by the state. Although foreign and joint-venture banks were allowed to operate, the regulatory regime was not well defined and few foreign banks had applied for a licence. Bank supervision was also weak. In this situation the government continued to intervene in the banking sector. In 1996 the National Bank of Belarus (NBB) and some commercial banks have been requested to earmark credits to some sectors of the economy, in particular agriculture and housing. During this year directed credits provided to agriculture at half of the monthly refinance rate accounted for $77 \%$ of total directed credits.

- Belarus 1997 - index of private entry in markets (enterprise reform) and 
index of trade and exchange rate regime

Progress with privatisation remained cumbersome (cf. 1996). Five large enterprises, explicitly targeted for privatisation in 1997, were not privatised. Succesive annual privatisation programmes approved since 1993 have always fallen short of their targets. Most of the privatisations of large state-owned enterprises habe been to management and employees; majority ownership and the transfer of decision making powers to private investors did not take place. The government intervened in capital and investment decisions and in the setting of price and production targets. In 1997 the government borrowed BRB 500 billion from the NBB to write off energy arrears accumulated by state-owned enterprises. Enterprise arrears to the budget increased in 1997, with profit tax arrears more than doubling during this year. Early 1998 commercial banks were ordered by the government to open a BRB 2 trillion subsidised credit line to agricutural enterprises on top of the allocation of BRB 0.5 trillion of soft credits.

In April 1996 the Minsk Interbank Currency Exchange (MICE) was nationalised and put under the direct control of the NBB. January 1997 a directive issued by the NBB limited purchases of hard currency and Russian roubles at the MICE. Furthermore the NBB reintroduced convertibility restrictions. Exporters were now required to surrender $40 \%$ of their foreign exchange earnings to the state at a highly overvalued exchange rate. During 1997 there was also a 107\% increase in net domestic credit by the National Bank of Belarus. The currency corridor vis-à-vis the dollar (established in January 1996, since April 1996 the nominal exchange rate was allowed to depreciate within a pre-established band) had to abandonned in 1997. Additionaly government efforts to maintain artificially low interest rates (interest rates in commercial banks are controlled by the government through the NBB) contributed to large capital flight to Russia, where interest rates were higher (in Belarus interest rates were negative in real terms).

- Belarus 1998 - index of price liberalisation

In March 1998 the Belarussian rouble plunged by 30\% following the 1997 increase in domestic credit. Lacking adequate foreign reserves, the National Bank of Belarus was unable to stabilise the Belarussian rouble. This led the government to pursue a range of administrative interventions (replacing existing informal price controls) in the market to prevent further price increases (and further devaluation). The government ordered both public and private enterprises to return prices to their pre-crisis level and banned any further price increases above $2 \%$ a month. During 1998 numerous regulations and restrictions on currency trade have been imposed and subsequently lifted at the discretion of the authorities, e.g. exporters required a special permit from the authorities for a number of goods, including some basic food and consumer products.

- Belarus 1999 - index of price liberalisation

During 1999 price controls were further tightened in an attempt to curb 
still accelerating inflation. In May 1999 a presidential decree banned any price increase that was not compensated for by measures of social protection, and mandated the Council of Ministers and the NBB to set annual limits for price indices. The decree also re-introduced state price regulation for a wide range of goods and services, including products and services supplied by monopolies, rents and basic foods and spirits. The government thus continued to rely on price controls as means of limiting inflation and allocating resources. While this resulted in a slow-down of inflation, inflation in Belarus remained the highest in all CIS countries, increasing far above the $2 \%$ monthly target.

- Bulgaria 1995 - index of price liberalisation

After an initial sweeping liberalisation of prices in 1991 covering about $90 \%$ of the consumer basket price controls were subsequently reintroduced. In 1995 , prices covering only about $54 \%$ of the consumer basket were free of administrative controls. Fixed prices applied to energy products ${ }^{14}$, post and telecoms, and tobacco products, and ceiling prices to most fuels. The monitoring of profit margins of both producers and traders applies to goods declared to be of vital importance to the living standards of the population (this includes basic food products, passenger transportation and certain non-food products as e.g. pharmaceuticals). Most importantly, a Price Law was passed by parliament enabling the government to introduce (further) price controls at its discretion. The administrative structure for price controls was strengthened further in a 1996 initiative envisaging local structures and a larger number of controllers (500 inspections in July 1996 alone).

- Kazakhstan 1999 - index of trade and foreign exchange liberalisation The backtracking in trade liberalisation created tensions with neighbouring countries. In early 1999 Kazakhstan impoased an import ban onselected Russian goods and $200 \%$ tariffs on similar items from Kyrgyzstan and Uzbekistan. Late 1999 the restrictions were lifted for the former two countries, whereas they remained in place for Uzbekistan. The introduction of product norms, such as a dual Russian and Kazakh language label, are also considered an implicit trade barrier by importters. Additionally, as part of the April 1999 devaluation package, a 50\% export surrender requirement was temporarily introduced (the requirment was lifted again end 1999).

- Kyrgyzstan 1999 - index of private entry in markets (banking sector reform)

An exchange rate depreciation and bank failures led to the collapse of the fragile Kyrgyz financial system (a.o. due to weak bank supervision and under-capitalisation ( very low minimum capital requirements)). Five of

${ }^{14}$ e.g. electricity prices remained among the lowest in the world, even after an increase of $25-38 \%$ in September 1995. 
the largest banks were either placed under conservatorship by the central bank or were liquidated in the first half of 1999. Two more banks were added to this list later on. Several banks had a large exposure to the state gas company which was affected by a large-scale fraud at the beginning of 1999. The failure to recognise and to respond to this problem revealed the weak supervision capabilities of the Central Bank. As a result of the collapse of the financial system access to new credit by the private sector became virtually non-existent. During 1999 the share of loans classified as substandard, doubtful or losses also rose from $7 \%$ to $25 \%$.

- Latvia 1998 - index of private entry in markets (banking sector reform) The high Russian exposure of some Latvian banks led to sharp losses in the aftermath of the Russian crisis. Operations o two smaller banks were suspended, while the ninth largest bank went bankrupt. Early 1999 the operations of the Rigas Commercial Bank (the fifth largest bank) also were suspended and a court declared the bank insolvent, in March the third largest bank, Rigas Komercbanka, was declared insolvent and closed. In response to the crisis, the central bank strengthened in 1998 regulatory requirments for banks, covering consolidated reporting and loan loss provisioning and maximum permissable exposures to borrowers in non-OECD countries.

- Romania 1996 - index of trade and foreign exchange liberalisation Access of enterprises to foreign exchange became more restricted in 1996 than it was in 1995. The lei was officially convertible for the purpose of foreign trade transactions and for repatriation of capital and profits of foreign investors. The exchange rate of the lei was floating, In August 1994 an interbank foreign exchange market was launched. From July 1995 onwards, foreign banks with local branches were granted permission to operate as dealers on this market. Exposure was limited both for dealers and brokers. In an attempt to control the downward tendency of the lei the authorities started to to impose increasingly tight restrictions on enterprises' access to conversion of lei into foreign currency and on the foreign curency operations of commercial banks in 1996. From March 1996 onwards only four banks could participate in the market; none of which was foreign and only one was not state-owned. In August, the government announced new surrender requirments for more than 100 firms; although these requirments were later given a more liberal interpretation in official announcements, the original decree remained in place.

- Romania 1998 - index of private entry in markets (banking sector reform) In 1998 the Romanian banking sector was still dominated by five large state-owned banks, accounting for about three quarters of total banking sector assets. These banks extended credit to loss-making state enterprises and thus accumulated large amounts of bad loans. Though the regulatory framework for bank supervision was improved with the adoption of three new laws in 1998, effective supervision remained constraint by political 
interference. A decision by the central bank (NBR) to revoke two bank licences was overruled by the courts in December 1997. The NBR also took on its books five-year bonds worth about USD 1 billion, issued by the Ministry of Finance to cover bad debts of the two largest state-owned banks, indicating a weak central bank independence and the use of inflationary bail-out operations.

- Russia 1998 - index of price liberalisation, index of trade and foreign exchange liberalisation, and index of private entry in markets

In 1998 Russia faced a severe currency crisis. August 17 the rouble-dollar corridor was widened substantially and a 90-day moratorium on foreign debt service by domestic banks and enterprises was imposed. Shortly afterwards additional pressure forced the central bank (CBR) to let the currency float beyond the new corridor. With surging prices and declining imports many regional governments introduced price controls (ranging from ceilings on profit margins to administered price-setting). To prevent food shortages restrictions were placed on the movement of selected locally products. Driven in part by budget revenue considerations export tariffs have been reintroduced for oil, gas, metals, petrochemicals and some other goods. The foreign exchange liberalisation was reversed. A range of currency restrictions were introduced, leading to a reversal of the degree of convertibility of the rouble. The currency market became segmented with a de facto multiple exchange rate regime. The surrender requirment for exporters was raised from $50 \%$ to $75 \%$, access of foreign banks to the foreign exchange market was limited and a deposit/advance payment system was introduced for import transactions.

A new bankruptcy law was enacted in March 1998. Though much improved, it was biased against private creditors, overemphasising restructuring at the expense of liquidation and provides extensive rights to local authorities in the bankruptcy of large enterprises. Moreover effective implementation did not match the improvement in the legal framework, weakening the bankruptcy threat. Moreover by backtracking in a number of high-profile bankruptcy cases, the government showed a lack of political will to allow the market to select enterprises for survival.

Due to a weak regulatory structure commercial banks dvelopped large foreign currency exposure. The currency crisis would have plunged nearly the entire banking system into insolvency if the government had not declared the moratorium. The crisis led to a run on the banks, a breakdown in the payments system, disruptions in tax collection and the collapse of financial intermediation. The initial response of the CBR exacerbated the problems through indiscriminate liquidity injections and inconsistent efforts to provide guarantees for household deposits.

- Russia 1999 - index of private entry in markets (banking sector reform, enterprise reform)

The restructuring of the banking system has been slow, uncoordinated 
and inefficient. The CBR e.g. provided "stabilisation credits" to troubled banks, but there was little control over the use of the money, and the basis on which the selection of banks was made was never defined. In general the CBR and the Organisation for Restructuring Credit Organisations (ARCO) -founded following the banking crisis- lacked the necessary skills and resources to accomplish an efficient and succesfull restructuring programme. The central bank turned out to be reluctant to protect the rights of bank creditors and to ensure that bank shareholders absorb losses, seriously impairing the efficacy of the regulatory and supervisory system, moreover the CBR failed to act rapidly to define clear rules for the restructuring programme.

Although the number of bankruptcy filings increased seriously, the outcomes were not clear and part of them reflected attempts by insiders to strip assets and political motivations rather than corporate restructuring processes. In early 1999 a number of legislative acts were passed to protect specific groups of enterprises (firms of strategic significance, regional energy distribution companies, agricultural firms) from bankruptcies and to stop the initiation of bankruptcies against tax debtors. Budgetary constraints for the enterprise sector remained soft.

- Slovak Republic 1997 - index of trade and foreign exchange liberalisation, index private entry in markets (enterprise reform)

Partly as a result of a persistent current account deficit, the government introduced a range of protectionist measures in the spring of 1997 . These included an import deposit scheme which forces importers to deposit $20 \%$ of the imported value for 180 days in an interest free account. However, the measure was replaced by the reintroduction of a $7 \%$ import surcharge. It applies to some $80 \%$ of all products. Other new import bariers include laws against subsidised and "excessive" imports. Additionally, mid-1997 the government reintroduced ${ }^{15}$ a wage regulation that limited wage growth of public and private firms to productivity gains.

Another worrying development that weakened market discipline -a law on the 'Revitalisation of Enterprises'- came into force mid-1997. A committee made up of government officials and bank executives will identify eligible companies which then receive state aid in the form of tax deferrals and debt forgiveness, conditional on criteria related to employment, social and regional development, as well as exports. These countries are also exempted from bankruptcy proceedings. This law induced over 1000 companies to apply for tax and debt relief.

In December 1997 the third largest bank -IRB- collapsed with estimated losses of about USD 100 million. It was put under forced administration of the central bank and received a significant liquidity injection.

- Tajikistan 1993 - index of price liberalisation

Limited price liberalisation was introduced in April 1991. In January 1992

${ }^{15}$ Wage controls were abolished late 1994. 
the governement lifted price controls on 80 per cent of goods. Further liberalisation of prices reduced the number of goods and servicesunder price controls to about 2 per cent of the total. Price controls mostly applied to the staple consumer goods such as flour and milk. In 1993 some price controls were reintroduced. Prices in industry were regulated under the monopoly law, and 17 basic consumer goods (including bread, rents and public transports) were controlled by executive order.

- Turkmenistan 1998 - index of private entry in markets (large-scale privatisation)

The private sector outside of agriculture accounted for less than $10 \%$ of GDP. All large enterprises were in the public sector. January 1998, a new privatisation centre was created at the State Agency for Foreign Investment (SAFI) with the immediate aim to privatise 18 large enterprises through international investment tenders. Only one of them, however, was sold to a domestic investor. This was due to the framework for privatisation that was created. In particular the practice of setting a reservation price equal to book value made the sale of firms very difficult because the true value of firms tended to be less than their book value, resulting in unrealistically high reservation prices. Social obligations placed upon owners of privatised firms and limited ownership rights regarding the land under enterprises further reduced the value of enterprises on offer.

- Turkmenistan 2000 - index of private entry in markets (enterprise reform) Off-budgetary investment funds, the President's control over most foreign currency reserves, the creation of a new President Bank and numerous tax concessions make for a highly discreationary business environment. Projects that receive presiential backing are rarely submitted to a market test, with all ensuing problems of endemic soft budget constraints. Government uses natural resource sector and its foreign exchange earnings to subsidise a largely outmoded domestic enterprise sector. A survey conducted in 2000 by UNDP and the government's statistical office revealed the difficult situation of most domestic entreprises. Only $28 \%$ of the 2014 enterprises reported positive growth prospects, $24 \%$ were close to bankruptcy and $48 \%$ were in financial difficulties. Taxation, limited access to foreign exchange, interference by the State Commodity Exchange and lack of access to affordable bank credit are cited as the biggest obstacles to private business. Despite improved liquidity in the enterprise sector and better revenue collection overall, arrears to the budget increased by $17 \%$ over the first half of 2000 and arrears to suppliers by $25 \%$.

- Ukraine 1998 - index of trade and foreign exchange liberalisation The collapse of the Russian rouble in August 1998 led to strong pressures on the Ukrainian hryvna. At the beginning of September the US Dollar currency band was widened. In order to keep the currency within the new band, the central bank introduced a number of restrictions on the foreign exchange market. These included e.g. a 50\% export revenue surrender 
requirment, a ban on foreign exchange trading in the interbank market and the introduction of various licences and permits, that were required to engage in foreign trade. A uniform $2 \%$ import surcharge was imposed for six months from the beginning of July (primarily to raise revenues). Many trading partners expressed their concern at the increase in import tariffs and trade barriers, especially to agricultural trade.

- Uzbekistan 1997 - index of price liberalisation and index of trade and foreign exchange liberalisation

Though most formal price controls had been abolished in 1996, administrative price controls were applied to energy, rents, communal services, public transport and telecommunications. In addition the government determined prices of a large number of monopoly products and monopoly enterprises. Procurement prices for cotton and wheat -for which the state order system was still in place- were also administratively set.

At the end of 1996, a general requirement for ex-ante registration of import contracts was in place, which basically functioned as an import-licensing system, reflecting the priorities of the authorities at that time and giving them effective control over imports. Additionally prepayment requirements were introduced. During 1997 customs duties and export licenses were abolished, but tariffs were increased.

At the beginning of 1997, an explicit multiple exchange rate regime was institutionalised (to support activities and investments in the government's priority sectors). The official rate was used mainly for accounting and customs purposes and for export proceeds under the obligatory surrender requirement. The auction rate was applied to importers and transactions enjoying priviliged access to foreign exchange, such as debt service payments or imported investment goods for high priority companies or projects. A special commercial (bank) rate was applied to imports of certain consumer goods and services. Both the auction and commercial bank rate were highly overvalued. A cash market rate is used by the foreign exchange bureaux of the eligible banks in their transactions with individuals. Lastly, there was a greatly expanded black market with a widely (though illegally) used black market rate. The difference between official and black market rates widened sharply since late 1996, with the latter oscillating at $40-50 \%$ of the official rate.

- Uzbekistan 1998 - index of price liberalisation

Further price controls were introduced. The process of price reform thus remained burdened with i) widespread use of preferential prices for selected customers, ii) new price distortions caused by the multiple exchange rate system and iii) non-transparent regulations for price formation of many products and enterprises.

- Uzbekistan 1999 - index of trade and foreign exchange liberalisation In a move targeted to protect reserves, foreign exchange surrender requirements on exports were increased from $30 \%$ to $50 \%$ in January 1999. Surren- 
dered foreign exchange was converted at the overvalued official exchange rate. Additionally Uzbekistan imposed high import duties on Kazakhstani and Kyrgyzstani imports and introduced barriers to shuttle trade.

- Uzbekistan 2000 - index of private entry in markets (enterprise reform) Import substitution policies in industry failed to boost output. According to an index of industrial production at constant prices, output fell by more than $10 \%$ during the two previous years. The decline is most pronounced among industries with a high share of foreign joint ventures, originally attracted as part of the country's industrialisation drive. Some companies decreased their output because of reduced subsidies but most of them reduced their production because of increasingly distorted prices and attempted government interventions in production plans.

Through a system of implicit and explicit taxation, the authorities transfer about $15 \%$ of GDP out of agriculture into the import substituting industries. A a result wages for farmers are a quarter of those in industry and there is underinvestment in the sector's infrastructure. 


\section{Appendix: Variable List and Data Sources}

\section{Description}

$\triangle G D P$ Real GDP growth, domestic currency, annual percentage change

$F B \quad$ Fiscal balance, general government

INF "End year inflation, transformed as $\ln (1+(I N F / 100))$

$R I \quad$ Reform index, weighted average (see De Melo et al. (1996))

$D \quad$ Reversal dummy $=1$ if $R I_{t}-R I_{t-1}<0$

$I C_{1,2} \quad$ Initial condition clusters

$F S \quad$ Freedom Status

\section{Data Sources}

$\triangle G D P \quad$ IMF, World Economic Outlook Database

$F B \quad$ EBRD Transition Report

INF EBRD Transition Report

$R I \quad$ Own calculations based on indicators in EBRD Transition Report

$D \quad$ idem

$I C_{1,2} \quad$ De Melo et al. (1997)

FS Freedom House, Nations in Transit + Country Rankings 


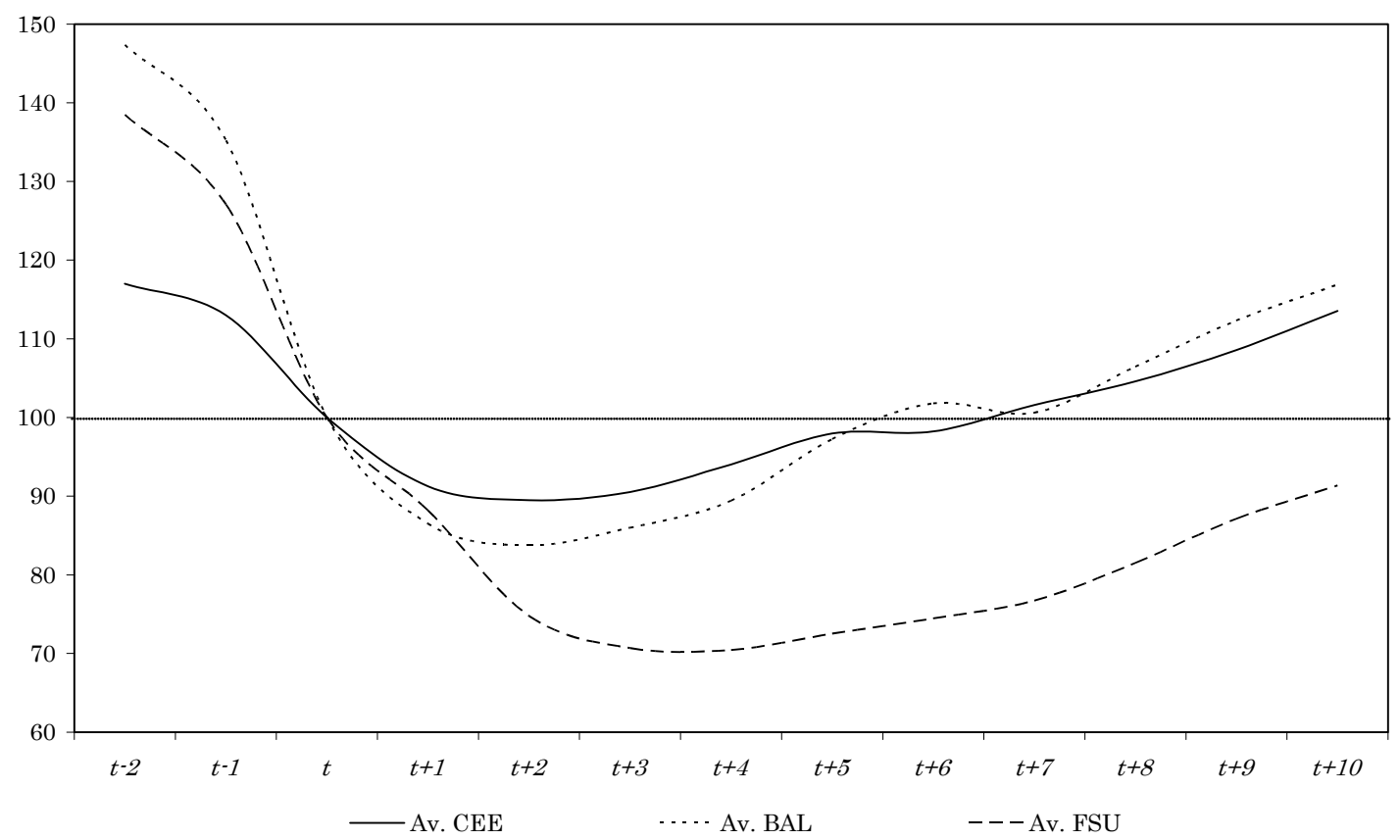

Figure 1: Output paths in transition timing of the average CEE-country, the average Baltic State and the average FSU-country (Source: IMF World Economic Outlook 2002) 

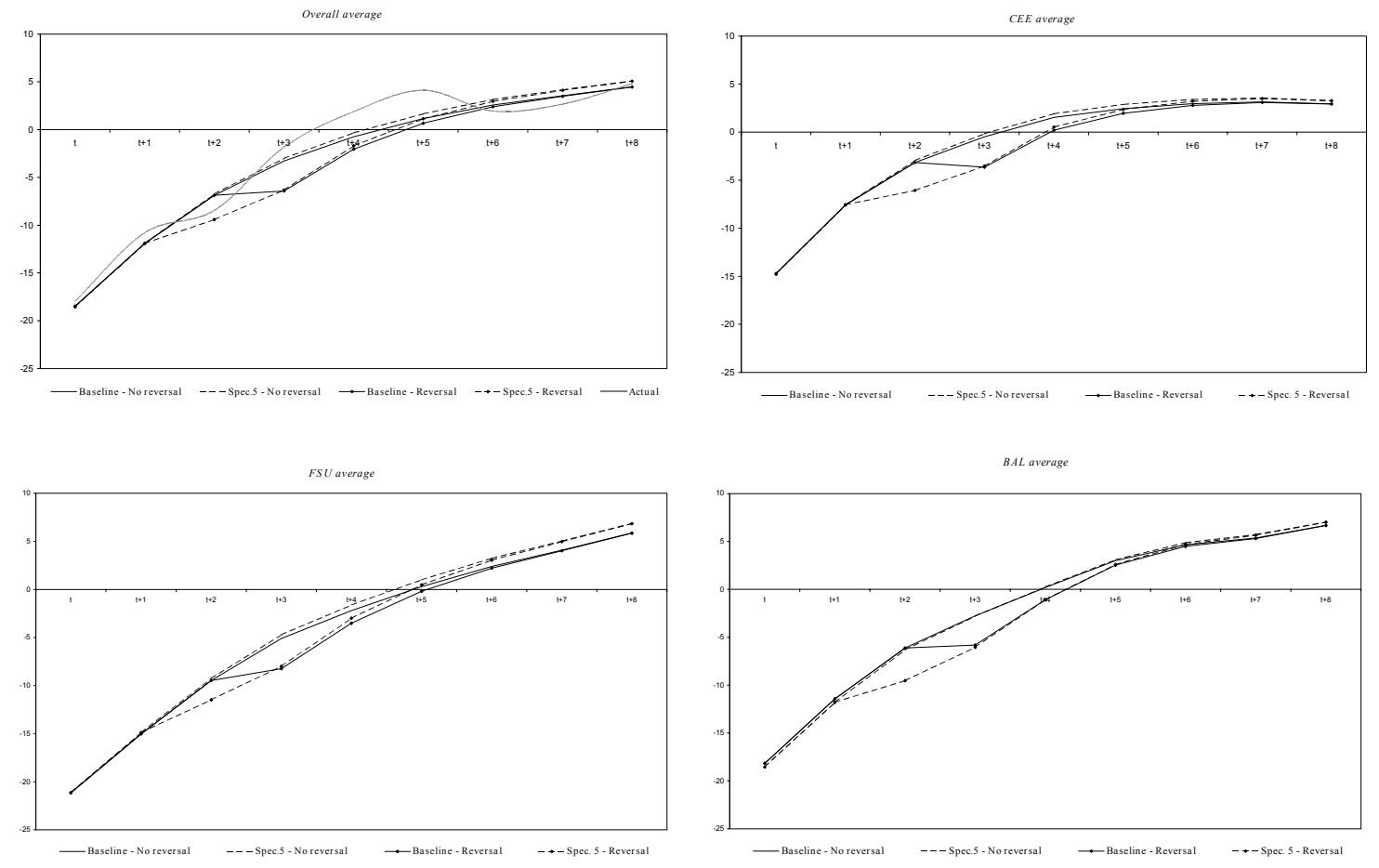

Figure 2: Simulated growth rates 

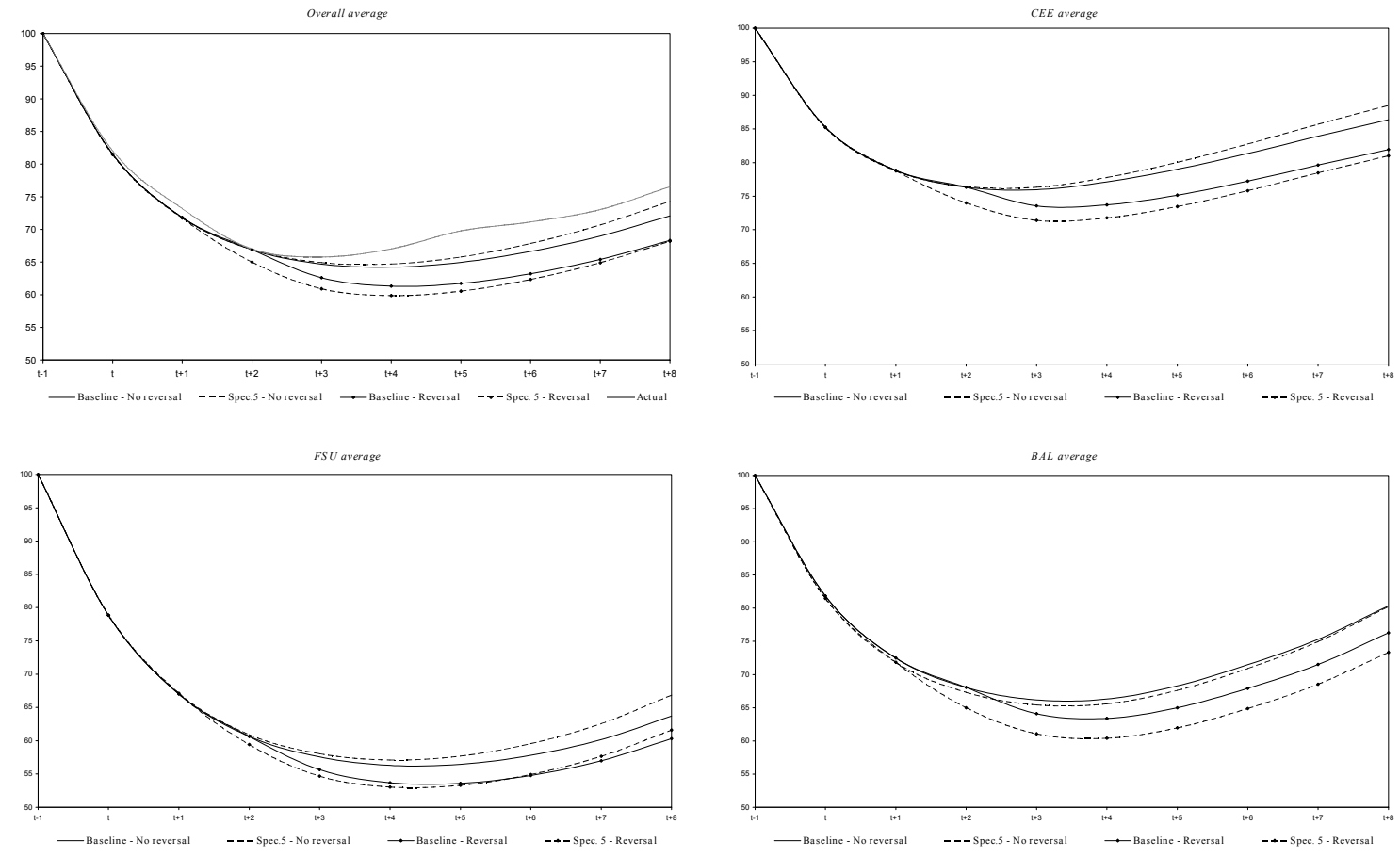

Figure 3: Simulated growth paths 

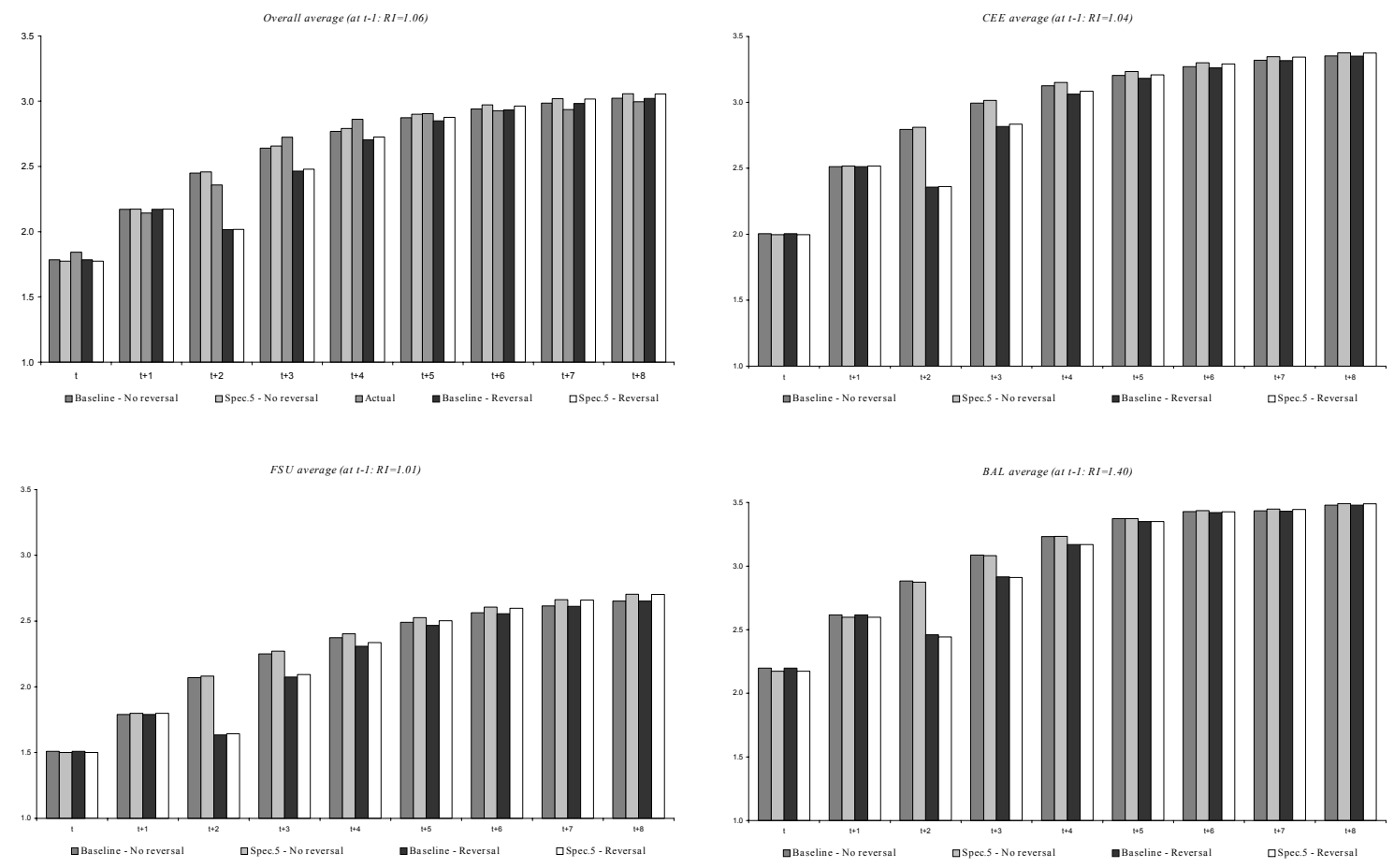

Figure 4: Simulated reform index 


\begin{tabular}{|c|c|c|c|c|c|}
\hline & [1] & [2] & [3] & [4] & [5] \\
\hline \multicolumn{6}{|l|}{$\Delta \mathrm{GDP}$} \\
\hline constant & $\begin{array}{c}-12.094 \\
(-1.10)\end{array}$ & $\begin{array}{c}-10.709 \\
(-0.87)\end{array}$ & $\begin{array}{l}-2.675 \\
(-0.18)\end{array}$ & $\begin{array}{l}-1.205 \\
(-0.08)\end{array}$ & $\begin{array}{c}-11.096 \\
(-0.94)\end{array}$ \\
\hline trend & $\begin{array}{l}3.202 \\
(2.16)\end{array}$ & $\begin{array}{l}4.014 \\
(2.09)\end{array}$ & $\begin{array}{l}4.035 \\
(2.21)\end{array}$ & $\begin{array}{l}5.228 \\
(2.40)\end{array}$ & $\begin{array}{l}3.744 \\
(2.13)\end{array}$ \\
\hline trend $^{2}$ & $\begin{array}{l}-0.128 \\
(-1.90)\end{array}$ & $\begin{array}{l}-0.163 \\
(-1.92)\end{array}$ & $\begin{array}{l}-0.168 \\
(-2.00)\end{array}$ & $\begin{array}{l}-0.231 \\
(-2.23)\end{array}$ & $\begin{array}{l}-0.151 \\
(-1.94)\end{array}$ \\
\hline trend*IC1 & $\begin{array}{l}0.706 \\
(4.65)\end{array}$ & $\begin{array}{l}0.782 \\
(4.83)\end{array}$ & $\begin{array}{l}0.493 \\
(2.51)\end{array}$ & $\begin{array}{l}0.365 \\
(1.58)\end{array}$ & $\begin{array}{l}0.766 \\
(4.86)\end{array}$ \\
\hline trend*IC2 & $\begin{array}{l}0.138 \\
(0.63)\end{array}$ & $\begin{array}{l}0.110 \\
(0.49)\end{array}$ & $\begin{array}{l}0.045 \\
(0.19)\end{array}$ & $\begin{array}{l}0.003 \\
(0.01)\end{array}$ & $\begin{array}{l}0.122 \\
(0.55)\end{array}$ \\
\hline RI & $\begin{array}{l}-5.139 \\
(-0.59)\end{array}$ & $\begin{array}{l}-8.347 \\
(-0.77)\end{array}$ & $\begin{array}{c}-14.239 \\
(-1.17)\end{array}$ & $\begin{array}{c}-17.860 \\
(-1.40)\end{array}$ & $\begin{array}{l}-7.460 \\
(-0.73)\end{array}$ \\
\hline $\mathrm{RI}_{-1}$ & $\begin{array}{l}9.334 \\
(2.46)\end{array}$ & $\begin{array}{c}10.788 \\
(2.24)\end{array}$ & $\begin{array}{c}11.885 \\
(2.43)\end{array}$ & $\begin{array}{c}12.666 \\
(2.56)\end{array}$ & $\begin{array}{c}10.514 \\
(2.31)\end{array}$ \\
\hline reversal* $\Delta \mathrm{RI}$ & & $\begin{array}{c}25.470 \\
(1.88)\end{array}$ & $\begin{array}{c}32.239 \\
(2.12)\end{array}$ & $\begin{array}{c}37.593 \\
(2.26)\end{array}$ & \\
\hline $\begin{array}{l}\text { reversal* } \\
\Delta \mathrm{RI}^{*} \mathrm{RI}_{-1}\end{array}$ & & & & & $\begin{array}{l}7.982 \\
(1.97)\end{array}$ \\
\hline fiscal bal. & $\begin{array}{l}0.231 \\
(2.46)\end{array}$ & $\begin{array}{l}0.223 \\
(2.30)\end{array}$ & & & $\begin{array}{l}0.221 \\
(2.35)\end{array}$ \\
\hline inflation & & & $\begin{array}{l}-3.449 \\
(-2.34)\end{array}$ & $\begin{array}{l}-3.597 \\
(-2.43)\end{array}$ & \\
\hline inflation-1 & & & & $\begin{array}{l}-0.976 \\
(-1.62)\end{array}$ & \\
\hline$R$-square & 0.63 & 0.62 & 0.58 & 0.55 & 0.63 \\
\hline Chi-square & 426.63 & 411.85 & 373.72 & 346.84 & 420.45 \\
\hline \multicolumn{6}{|l|}{ RI } \\
\hline constant & $\begin{array}{l}1.759 \\
(6.99)\end{array}$ & $\begin{array}{l}1.760 \\
(6.95)\end{array}$ & $\begin{array}{l}1.729 \\
(6.72)\end{array}$ & $\begin{array}{l}1.734 \\
(6.66)\end{array}$ & $\begin{array}{l}1.758 \\
(6.95)\end{array}$ \\
\hline trend*IC1 & $\begin{array}{c}-0.34 \\
(-3.75)\end{array}$ & $\begin{array}{l}-0.035 \\
(-3.78)\end{array}$ & $\begin{array}{l}-0.035 \\
(-3.72)\end{array}$ & $\begin{array}{l}-0.035 \\
(-3.64)\end{array}$ & $\begin{array}{l}-0.035 \\
(-3.78)\end{array}$ \\
\hline trend*IC2 & $\begin{array}{c}-0.12 \\
(-0.93)\end{array}$ & $\begin{array}{l}-0.013 \\
(-0.96)\end{array}$ & $\begin{array}{c}-0.13 \\
(-0.99)\end{array}$ & $\begin{array}{l}-0.012 \\
(-0.93)\end{array}$ & $\begin{array}{l}-0.013 \\
(-0.96)\end{array}$ \\
\hline$\Delta \mathrm{GDP}$ & $\begin{array}{c}0.056 \\
(13.91)\end{array}$ & $\begin{array}{c}0.057 \\
(13.83)\end{array}$ & $\begin{array}{c}0.058 \\
(13.70)\end{array}$ & $\begin{array}{c}0.059 \\
(13.39)\end{array}$ & $\begin{array}{c}0.057 \\
(13.89)\end{array}$ \\
\hline$\Delta \mathrm{GDP}_{-1}$ & $\begin{array}{l}-0.003 \\
(-1.38)\end{array}$ & $\begin{array}{l}-0.003 \\
(-1.34)\end{array}$ & $\begin{array}{l}-0.005 \\
(-1.72)\end{array}$ & $\begin{array}{l}-0.007 \\
(-2.06)\end{array}$ & $\begin{array}{l}-0.003 \\
(-1.33)\end{array}$ \\
\hline $\begin{array}{r}\text { freedom } \\
\text { status }\end{array}$ & $\begin{array}{l}0.813 \\
(2.53)\end{array}$ & $\begin{array}{l}0.788 \\
(2.43)\end{array}$ & $\begin{array}{l}0.834 \\
(2.54)\end{array}$ & $\begin{array}{l}0.834 \\
(2.57)\end{array}$ & $\begin{array}{l}0.793 \\
(2.45)\end{array}$ \\
\hline$R$-square & 0.72 & 0.71 & 0.70 & 0.69 & 0.71 \\
\hline Chi-square & 770.15 & 764.45 & 739.14 & 712.53 & 766.94 \\
\hline$N$ & 237 & 237 & 237 & 236 & 237 \\
\hline
\end{tabular}

Table 1: 3SLS estimation results 


\begin{tabular}{lccccc}
\hline \hline & $r$ & $r+1$ & $r+2$ & $r+3$ & $r+4$ \\
\hline \hline reversal & & & & & \\
-0.025 & 0.13 & 0.02 & -0.08 & -0.19 & -0.29 \\
& -0.43 & -0.49 & -0.55 & -0.61 & -0.67 \\
-0.050 & 0.26 & 0.05 & -0.16 & -0.37 & -0.58 \\
& -0.86 & -0.98 & -1.10 & -1.22 & -1.34 \\
-0.100 & 0.51 & 0.09 & -0.33 & -0.74 & -1.16 \\
& -1.71 & -1.96 & -2.20 & -2.44 & -2.69 \\
-0.155 & 0.80 & 0.15 & -0.50 & -1.15 & -1.80 \\
& -2.65 & -3.03 & -3.41 & -3.79 & -4.17 \\
-0.300 & 1.54 & 0.28 & -0.98 & -2.23 & -3.49 \\
& -5.14 & -5.87 & -6.60 & -7.33 & -8.07 \\
-0.700 & 3.60 & 0.66 & -2.28 & -5.21 & -8.15 \\
& -11.99 & -13.69 & -15.40 & -17.11 & -18.82 \\
\hline \hline
\end{tabular}

Table 2: Cumulated impact on growth of a reversal: comparison between estimation [1] and [2]

\begin{tabular}{lllllll}
\hline \hline & 1.50 & 2.00 & 2.50 & 3.00 & 3.50 & 4.00 \\
\hline \hline until r & -0.70 & -1.32 & -1.94 & -2.56 & -3.17 & -3.79 \\
until r+1 & -1.17 & -1.79 & -2.41 & -3.03 & -3.65 & -4.27 \\
until r+2 & -1.65 & -2.26 & -2.88 & -3.50 & -4.12 & -4.74 \\
until $\mathrm{r}+3$ & -2.12 & -2.74 & -3.36 & -3.97 & -4.59 & -5.21 \\
until $\mathrm{r}+4$ & -2.59 & -3.21 & -3.83 & -4.45 & -5.07 & -5.69 \\
\hline
\end{tabular}

Table 3: Cumulated impact of a reversal of -0.155 based on [6] (row headings denote the value of the lagged stock at the time the reversal occurrs) 